DOI: 10.15290/aipan.2020.09

\title{
Wspieranie zatrudnienia osób niepełnosprawnych na otwartym rynku pracy
}

\author{
Aneta Giedrewicz-Niewińska \\ Uniwersytet w Białymstoku \\ a.niewinska@uwb.edu.pl \\ ORCID: https://orcid.org/0000-0003-0780-192X
}

\section{Uwagi ogólne}

Osoby niepełnosprawne z pewnością znajdują się w trudniejszej sytuacji zawodowej niż osoby w pełni sprawne. Towarzyszą im ograniczenia związane z wyborem zawodu, jego zmianą, z uzyskaniem odpowiednich kwalifikacji, a także ze znalezieniem zatrudnienia i następnie $\mathrm{z}$ jego utrzymaniem. Istnieje zatem potrzeba wsparcia osób niepełnosprawnych. Nie można nie zauważyć, że wynika ona z moralnego obowiązku wypływającego z solidaryzmu społecznego. Ponadto nakaz ochrony osób niepełnosprawnych przed sytuacjami społecznego wykluczenia można odczytać z całokształtu przepisów konstytucyjnych ${ }^{1}$. Konstytucyjne obowiązki państwa w tym zakresie określa art. 69 Konstytucji RP, w myśl którego osobom niepełnosprawnym władze publiczne udzielają, zgodnie z ustawą, pomocy w zabezpieczeniu egzystencji, przysposobieniu do pracy oraz komunikacji społecznej. W powyżej wskazanym obowiązku władz publicznych mieści się przysposobienie do pracy, co oznacza tworzenie szczególnych programów szkoleniowych i przystosowawczych, wprowadzenie systemu zachęt i ułatwień dla zatrudnienia osób niepełnosprawnych ${ }^{2}$. Przepis ten łączy się ściśle z nakazem poszanowania godności człowieka (art. 30 Konstytucji) oraz z zakazem dyskryminacji (art. 32 Konstytucji).

Nie ulega wątpliwości, że zatrudnienie osób niepełnosprawnych na otwartym rynku pracy ma istotne znaczenie. Wystarczy wskazać, iż pomaga w większym stop-

$\begin{array}{ll}1 & \text { L. Garlicki, M. Derlatka, [w:] Konstytucja Rzeczypospolitej Polskiej. Komentarz, t. 2, Warszawa 2016, s. } 743 . \\ 2 & \text { Ibidem, s. } 743 .\end{array}$ 
niu niż praca na rynku chronionym integrować się ze społeczeństwem. W związku z powyższym w odniesienia do zatrudnienia osób niepełnosprawnych na otwartym rynku pracy na szczególne podkreślenie zasługuje zasada równego traktowania w zatrudnieniu, wyrażona w rozdziale II $^{\mathrm{a}}$ Kodeksu pracy (k.p. $)^{3}$.

Regulacja dotycząca wspierania zatrudnienia osób niepełnosprawnych istnieje już od dłuższego czasu. Problematyka ta może się wydawać już dawno omówiona, jednak przepisy te nadal wywołują wątpliwości. Spowodowane są one kolejnymi nowelizacjami ustawy z dnia 27 sierpnia 1997 r. o rehabilitacji zawodowej i społecznej oraz zatrudnianiu osób niepełnosprawnych ${ }^{4}$, systemem odesłań zastosowanych w ustawie, a także - jak pokazuje praktyka - pojawiającymi się nowymi problemami. Stąd omówienie powyższych zagadnień wydaje się uzasadnione.

\section{System kwotowy}

Jednym z działań wspierających dostęp osób niepełnosprawnych do zatrudnienia na otwartym rynku pracy jest tzw. system kwotowy. Jego istota sprowadza się do obowiązku osiągania przez pracodawców wymaganego wskaźnika zatrudnienia osób niepełnosprawnych oraz skutków niezrealizowania tego obowiązku.

Wspomniany wyżej system jest obecny w prawie polskim, m.in. w ustawie o rehabilitacji. Zgodnie $\mathrm{z}$ art. 21 cytowanej ustawy pracodawca ${ }^{5}$ zatrudniający co najmniej 25 pracowników w przeliczeniu na pełny wymiar czasu pracy jest obowiązany dokonywać miesięcznych wpłat na Państwowy Fundusz Rehabilitacji Osób Niepełnosprawnych (PFRON). Od tej generalnej zasady przepis jednak statuuje wyjątki.

W celu zachęcenia pracodawców do zatrudniania osób niepełnosprawnych przewidziano zwolnienie z powyższych opłat, jeżeli wskaźnik zatrudnienia takich osób wynosi co najmniej 6\%. Kwota składek na PFRON ulega odpowiedniemu

$4 \quad$ Zob. tekst jedn. Dz.U. z 2020 r. poz. 426.

$5 \quad$ W związku z tym, że ustawa o rehabilitacji zawodowej nie zawiera własnej definicji pracodawcy, stosuje się do niej art. 3 k.p. (wyrok WSA w Warszawie z dnia 31 maja 2006 r., III SA/Wa 353/06, Legalis nr 320881). Zgodnie z tym przepisem pracodawca jest jednostka organizacyjna choćby nie posiadała osobowości prawnej, a także osoba fizyczna, jeżeli zatrudniają pracowników. Przymiot pracodawcy - osoby fizycznej zatrudniającej pracowników w kancelarii komorniczej w związku z prowadzoną osobiście szczególną działalnością zawodową - przysługuje, jak stwierdził WSA w Warszawie, także komornikowi. W konsekwencji na takim komorniku jako pracodawcy ciążyć może obowiązek wpłat na rzecz PFRON - na podstawie art. 21 ust. 1 ustawy o rehabilitacji (wyrok WSA w Warszawie z dnia 22 listopada 2016 r., III SA/Wa 2694/15, LEX nr 2260907). Szerzej na ten temat kontrowersji związanych z pojęciem pracodawcy zob. M. Paluszkiewicz, [w:] Ustawa o rehabilitacji zawodowej i społecznej oraz zatrudnianiu osób niepełnosprawnych. Komentarz, red. M. Włodarczyk, Warszawa 2015, s. 426-428. 
zmniejszeniu, w przypadku gdy wskaźnik zatrudnienia osób niepełnosprawnych ${ }^{6}$ jest wyższy niż 0\%, a niższy niż 6\%. Ustawodawca wskazuje również pracodawców, u których przewiduje niższy niż $6 \%$ wskaźnik zatrudnienia osób niepełnosprawnych (art. 21 ust. 2b) oraz pracodawców z obniżoną wpłatą na PFRON, jeżeli zatrudniają osoby, u których stwierdzono jedno ze szczególnych schorzeń (art. 21 ust. 4) ${ }^{7}$.

Ponadto niektóre jednostki ustawodawca zwalnia z obowiązku dokonywania miesięcznych wpłat na PFRON z tytułu nieosiągania wymaganego poziomu zatrudnienia osób niepełnosprawnych (m.in. niedziałające w celu osiągnięcia zysku: domy pomocy społecznej, hospicja, zakłady opiekuńczo-lecznicze, pracodawcy, co do których ogłoszono upadłość).

System kwotowy wspierania zatrudniania osób niepełnosprawnych obowiązuje również w sektorze publicznym w toku procesu rekrutacji. Rozwiązania te mają na celu zwiększenie niskich wskaźników zatrudnienia osób niepełnosprawnych we wskazanym obszarze. Bardziej korzystne traktowanie osób posiadających powyższą cechę prawnie chronioną wskazuje ustawa z dnia 21 listopada 2008 r. o służbie cywilnej ${ }^{8}$ i ustawa o pracownikach samorządowych (odpowiednio art. 29a ust. 2 oraz art. 13 a ust. 2$)^{9}$. Ustalono w tych aktach wskaźnik zatrudnienia osób niepełnosprawnych również na poziomie 6\%. Nieosiągnięcie tego wskaźnika w miesiącu poprzedzającym miesiąc dokonywania rekrutacji kandydatów na stanowisko urzędnicze powoduje tzw. pierwszeństwo w zatrudnieniu dla osoby niepełnosprawnej.

Zasada pierwszeństwa nie jest jednak bezwarunkowa. Obowiązuje tylko w sytuacji, gdy osoba niepełnosprawna przeszła do etapu konkursu na stanowisko, w którym komisja wyłania nie więcej niż pięciu najlepszych kandydatów spełniających wymagania konkursowe w celu przedstawienia kierownikowi jednostki do zatrudnienia wybranego kandydata. Jeżeli w gronie wyłonionych najlepszych pięciu osób znajdzie się osoba niepełnosprawna, to bez względu na wyniki pozostałych kandydatów pierwszeństwo w zatrudnieniu uzyska osoba niepełnosprawna.

Należy podkreślić, że jeżeli w piątce najlepszych kandydatów znajdzie się więcej niż jedna osoba niepełnosprawna, do wyboru kandydata na wolne stanowisko niezbędne jest porównanie stopnia spełniania stawianych wymogów przez te osoby. Decydujący w takich przypadkach nie może być stopień niepełnosprawności.

6 Wskaźnik zatrudnienia osób niepełnosprawnych oznacza, w rozumieniu art. 2 pkt 6 ustawy o rehabilitacji, przeciętny miesięczny udział procentowy osób niepełnosprawnych w zatrudnieniu ogółem w przeliczeniu na pełny wymiar czasu pracy.

Wykaz rodzaju schorzeń znajduje się w rozporządzeniu Ministra Pracy i Polityki Socjalnej z dnia 18 września 1998 r. w sprawie rodzajów schorzeń uzasadniających obniżenie wskaźnika zatrudnienia osób niepełnosprawnych oraz sposobu jego obniżenia (Dz.U. z 1998 r. Nr 124, poz. 820).

9 Zob. tekst jedn. Dz.U. z 2019 r. poz. 1282 z późn. zm. 
Podstawowym problemem, jaki pojawia się na tle cytowanych wyżej przepisów ustawy o pracownikach samorządowych i o służbie cywilnej, jest to, w jaki sposób można zakwestionować zapadłe rozstrzygnięcie w kwestii odmowy zatrudnienia osoby niepełnosprawnej. Z powołanych powyżej przepisów wynika, że ustawodawca pozostawił pracodawcy swobodę $\mathrm{w}$ dokonaniu wyboru najlepszego kandydata spośród zgłoszonych ofert. W związku z powyższym pojawia się pytanie, jaka jest procedura odwoławcza lub kontrolna w sytuacji, w której komisja konkursowa odmawia dopuszczenia do kolejnego etapu postępowania konkursowego (np. rozmowy kwalifikacyjnej). W powołanych wyżej ustawach nie ma wprost przepisów pozwalających na merytoryczną, sądową weryfikację naboru na stanowisko.

W związku z tym, że kwestia ta ma istotne znaczenie dla omawianego środka wsparcia zatrudnienia osób niepełnosprawnych, warto przyjrzeć się stanowi faktycznemu, jaki zaistniał w sprawie rozstrzyganej przez Wojewódzki Sąd Administracyjny we Wrocławiu ${ }^{10}$. Zagadnienie to pojawiło się w związku z niedopuszczeniem niepełnosprawnego kandydata przez komisję konkursową do trzeciego etapu konkursu na stanowisko starszego specjalisty i w rezultacie tej czynności uchylenie się przez dyrektora generalnego urzędu wojewódzkiego od zatrudnienia tej osoby na tym stanowisku. Gdyby osoba ta zakwalifikowała się do ostatniego etapu konkursu, w myśl zasady pierwszeństwa dyrektor generalny byłby zobowiązany do jej zatrudnienia. Kandydat zakwestionował ocenę komisji konkursowej w kwestii jego pisemnej wypowiedzi jako arbitralną i nieodzwierciedlającą faktycznego poziomu umiejętności. Jego zdaniem organ arbitralnie przypisywał punktację do zadań uczestników konkursu.

Wojewódzki Sąd Administracyjny we Wrocławiu orzekł, że poszczególne czynności komisji konkursowej podejmowane w toku postępowania konkursowego nie mają charakteru samodzielnego i odrębnego. Stanowią pewien ciąg zdarzeń, a etapem kończącym to postępowanie jest protokół z naboru, na podstawie którego publikuje się wyniki konkursu. Oznacza to, że każda z czynności komisji konkursowej podejmowanych w toku naboru, bez względu na to, na którym etapie konkursu została podjęta, wymyka się spod kontroli sądu administracyjnego. Dotyczy to również niedopuszczenia do kolejnego etapu konkursu.

Zasadniczą kwestią jest zatem ustalenie, czy zagadnienia dotyczące naboru do służby cywilnej powinny być rozpatrywane przez sądy pracy. Z pewnością jest to możliwe, gdy ocena naboru dokonywana jest w świetle zasady równego traktowania w zatrudnieniu. W pozostałym zakresie - zarówno w orzecznictwie, jak i w doktrynie - powstały rozbieżności. 
Punktem wyjścia do rozważań stał się w tym przypadku art. 9 ust. 1 ustawy o służbie cywilnej, zgodnie z którym w sprawach dotyczących stosunku pracy w służbie cywilnej, nieuregulowanych w ustawie, stosuje się przepisy Kodeksu pracy i inne przepisy prawa pracy. W myśl ust. 2 tego artykułu spory o roszczenia dotyczące stosunku pracy w służbie cywilnej rozpatrywane są przez sądy pracy.

Sąd Najwyższy w uchwale składu siedmiu sędziów z dnia 29 czerwca 2006 r. ${ }^{11}$ orzekł, iż do spraw wynikających z postępowania konkursowego nie stosuje się przepisów Kodeksu pracy i innych przepisów prawa pracy. Żądanie ponownego przeprowadzenia konkursu (uchylenie decyzji konkursowej, unieważnienie konkursu i wyznaczenie skarżącego na kandydata na stanowisko), zdaniem sądu, nie jest sprawą (roszczeniem) wynikającym ze stosunku pracy, lecz żądaniem o charakterze wybitnie publicznoprawnym. Ponadto, jak stwierdził sąd, osoba, która uczestniczyła w postępowaniu konkursowym i nie została wyłoniona w jego wyniku jako kandydat na odpowiednie stanowisko, nie jest członkiem korpusu służby cywilnej i nie pozostaje w stosunku pracy. W związku z tym nie przysługują jej roszczenia przewidziane w Kodeksie pracy i innych przepisach prawa pracy.

Część przedstawicieli doktryny poparła cytowane stanowisko Sądu Najwyższego. W myśl tych poglądów nabór zmierzający do wyłonienia kandydata na stanowisko w służbie cywilnej jest postępowaniem z zakresu administracji publicznej, a jego wynik podlega kontroli sądu administracyjnego ${ }^{12}$.

Problem procedury kontrolnej naboru w służbie cywilnej nadal nie jest jednak sprawą oczywistą, o czym świadczą wciąż pojawiające się odmienne od stanowiska Sądu Najwyższego orzeczenia sądów administracyjnych i wypowiedzi przedstawicieli doktryny. Przykładowo, w jednym z postanowień, z dnia 14 maja 2013 r. ${ }^{13}$, sąd administracyjny uznał, że sąd pracy, a nie sąd administracyjny jest właściwy do rozstrzygnięcia sporu, w którego następstwie pozbawiono skarżącego możliwości ubiegania się o określone stanowisko, zamykając drogę do powstania stosunku pracy pomiędzy skarżącym a urzędem. Zdaniem sądu z Kodeksu pracy wynika jednoznacznie, że zagadnienie nawiązania stosunku pracy mieści się w pojęciu spraw związanych ze stosunkiem pracy (patrz dział drugi Kodeksu pracy), natomiast nabór na stanowisko w służbie cywilnej stanowi swoisty element nawiązania stosunku pracy.

11 III PZP 1/06, OSNAPiUS 2007, nr 3-4, poz. 37, s. 90, z glosą H. Szewczyk, OSP 2007, z. 12, s. 900 i n. Odmiennie H. Szewczyk w glosie do postanowienia SN z dnia 13 października 2005 r., II PK 337/04, OSP 2007, z. 7-8, poz. 93, s. 577-580. i Zabezpieczenie Społeczne" 2009, nr 8, s. 19; J. Stelina, Prawo urzędnicze, Warszawa 2009, s. 180-181.

13 Postanowienie WSA w Warszawie $z$ dnia 14 maja 2013 r., IV SA/Wa 595/13, Legalis nr 846376; podobnie postanowienie WSA w Warszawie z dnia 13 czerwca 2011 r., VII SA/Wa 2354/10, Legalis nr 510158. 
W dalszym ciągu są prezentowane w literaturze poglądy, w myśl których kandydaci biorący udział w procedurze naboru powszechnego do służby cywilnej mogą kwestionować wyniki postępowania rekrutacyjnego przed sądem pracy ${ }^{14}$. Ponadto zauważa się, że art. 9 ustawy o służbie cywilnej uprawnia do rozszerzającej wykładni, obejmując relacje pracownicze pośrednio związane ze stosunkiem pracy w służbie cywilnej oraz sprawy o roszczenia związane ze stosunkiem pracy ${ }^{15}$.

Wydaje się, że należy przychylić się do dominującego stanowiska, wyrażonego w uchwale Sądu Najwyższego z 29 czerwca 2006 r., w myśl którego naruszenie przepisów dotyczących naboru powszechnego umożliwia uczestnikowi odwołanie się do sądu administracyjnego. Jak stwierdził SN, wynik konkursu nie jest źródłem stosunku zobowiązaniowego, lecz decyzją administracyjną kształtującą autorytatywnie prawa i obowiązki publicznoprawne wszystkich uczestników konkursu. Wydaje się jednak, iż potrzebne jest jednoznaczne uregulowanie w ustawie o służbie cywilnej i w ustawie o pracownikach samorządowych procedury kwestionowania prawidłowości przeprowadzonego naboru na stanowisko.

\section{Wspieranie pracodawców w zakresie dodatkowych kosztów zatrudniania niepełnosprawnych}

Działania wyrównawcze $\mathrm{w}$ zakresie dostępu osób niepełnosprawnych do otwartego rynku pracy polegają również na rekompensowaniu pracodawcom dodatkowych kosztów związanych z zatrudnianiem osób niepełnosprawnych ze środków publicznych. Zakres i cel refundacji jest zróżnicowany. Według ustawy o rehabilitacji pracodawcy mogą ubiegać się o:

- miesięczne dofinansowanie do wynagrodzeń pracowników niepełnosprawnych (art. 26 a),

- zwrot dodatkowych kosztów związanych z zatrudnianiem pracowników niepełnosprawnych (art. 26),

- zwrot kosztów wyposażenia stanowiska pracy (art. 26e),

- refundację kosztów szkolenia pracowników niepełnosprawnych (art. 26d).

Ustawodawca pozwala pracodawcy ubiegać się o miesięczne dofinansowanie jedynie na nowo zatrudnionego pracownika niepełnosprawnego. Oznacza to, że chodzi o pracownika, z którym nie był wcześniej związany stosunkiem pracy ${ }^{16}$. Dotyczy to również sytuacji, $\mathrm{w}$ której miejsce pracy tego pracownika powstało wskutek zmniejszenia wymiaru czasu pracy pracownika na jego wniosek lub wygaśnięcia

14 H. Szewczyk, Stosunki pracy w służbie cywilnej, Warszawa 2010, s. 96.

15 K.W. Baran, [w:] Prawo urzędnicze. Komentarz, Warszawa 2014, s. 68 i 69.

16 J. Knapińska, Nowe zasady wspierania pracodawców osób niepełnosprawnych, „Służba Pracownicza” 2009, nr 5, s. 10. 
umowy o pracę w rozumieniu Kodeksu pracy. Zgodzić się należy, że intencją ustawodawcy było ograniczenie przypadków zwalniania pełnosprawnych pracowników w celu zatrudnienia osób niepełnosprawnych i otrzymania dofinansowania ${ }^{17}$. W kontekście tej formy pomocy w literaturze pozytywnie ocenia się „efekt zachęty” zastosowany przez ustawodawcę, który uzależnił uzyskanie dofinansowania od wykazania, że zatrudnienie pracownika niepełnosprawnego doprowadziło do wzrostu netto stanu zatrudnienia ogółem i wzrostu netto stanu zatrudnienia osób niepełnosprawnych ${ }^{18}$. Chodzi tym samym o regulacje mające prowadzić do faktycznego, a nie pozornego zwiększenia zatrudnienia u danego pracodawcy. Krytykuje się natomiast okoliczność, że system dofinansowania wynagrodzeń nie jest związany $\mathrm{z}$ podejmowaniem przez pracodawcę działań związanych $\mathrm{z}$ podnoszeniem przez pracownika kwalifikacji zawodowych ${ }^{19}$.

W orzecznictwie stwierdza się, że wysokość miesięcznego dofinansowania jest uzależniona od faktycznego poniesienia kosztów płacy, w tym również wynikających ze składek na ubezpieczenie społeczne i zdrowotne oraz pozostałych obowiązkowych składek, które opłacane są w wynikających z prawa terminach ${ }^{20}$. W związku z powyższym opóźnienia skutkiem stwierdzenia nieterminowego poniesienia kosztów płacy jest sankcja w postaci braku możliwości uzyskania dofinansowania przez pracodawcę ${ }^{21}$.

Należy zauważyć, że część finansowego wsparcia kierowana jest do osób niepełnosprawnych o statusie bezrobotnych lub poszukujących pracy, niepozostających $\mathrm{w}$ zatrudnieniu ${ }^{22}$. Przede wszystkim dotyczy to zwrotu kosztów związanych $\mathrm{z}$ adaptacją pomieszczeń lub urządzeń, zakupu lub autoryzacji oprogramowania na użytek pracowników niepełnosprawnych oraz urządzeń technologii wspomagających lub przystosowanych do potrzeb wynikających z ich niepełnosprawności (tzw. dodatkowe koszty zatrudnienia ${ }^{23}$ ), a także kosztów wyposażenia stanowiska ${ }^{24}$. Możliwość ubiegania się o zwrot tych kosztów powstaje wyłącznie w przypadku zatrudnienia przez okres co najmniej 36 miesięcy niepełnosprawnych posiadających

17 Ibidem, s. 10 .

18 L. Klimkiewicz, Dofinansowanie do wynagrodzeń - tylko z efektem zachęty, „Służba Pracownicza” 2010, nr 6, s. 17 in.

19 K. Roszewska, Zatrudnianie i aktywizacja zawodowa osób z niepełnosprawnościami, [w:] Najważniejsze wyzwania po ratyfikacji przez Polskę Konwencji ONZ o prawach osób niepełnosprawnych, „Biuletyn Rzecznika Praw Obywatelskich" 2012, nr 10, s. 53.

20 Wyrok NSA z dnia 13 grudnia 2017 r., II GSK 2782/17, LEX nr 2435573.

21 Wyrok WSA w Warszawie z dnia 15 stycznia 2019 r., V SA/Wa 1632/18, LEX nr 2643607; wyrok WSA w Warszawie z dnia 18 października 2018 r., V SA/Wa 1631/18, LEX nr 2643547.

22 E. Staszewska, Środki prawne przeciwdziałania bezrobociu, Warszawa 2012, s. 238.

23 Szczegóły uregulowane zostały w rozporządzeniu Ministra Pracy i Polityki Społecznej z dnia 23 grudnia 2014 r. w sprawie zwrotu dodatkowych kosztów związanych z zatrudnianiem pracowników niepełnosprawnych (Dz.U. z 2014 r. poz. 1987).

24 Szczegóły uregulowane zostały w rozporządzeniu Ministra Pracy i Polityki Społecznej z dnia 11 marca 2011 r. w sprawie zwrotu kosztów wyposażenia stanowiska pracy osoby niepełnosprawnej (Dz.U. z 2015 r. poz. 93). 
powyższy status. Zauważa się, że ustawodawca, przyznając refundację pracodawcom przyjmującym osoby niepełnosprawne do pracy, nieposiadające statusu bezrobotnego, podejmuje również istotne działania prewencyjne ${ }^{25}$.

Wymienione powyżej koszty zatrudnienia pracownika niepełnosprawnego są w istocie, jak się wydaje, przykładem niezbędnych racjonalnych usprawnień, wskazanych w art. 23a ust. 1 ustawy o rehabilitacji zawodowej. Przepis ten wprowadza pojęcia nieostre i niezdefiniowane przez ustawodawcę ${ }^{26}$. Racjonalne usprawnienia polegają, według ustawodawcy, na przeprowadzeniu koniecznych w konkretnej sytuacji zmian lub dostosowań do szczególnych, zgłoszonych pracodawcy potrzeb wynikających z niepełnosprawności danej osoby, o ile przeprowadzenie takich zmian lub dostosowań nie skutkuje nałożeniem na pracodawcę nieproporcjonalnie wysokich obciążeń. Obciążenia nie są nieproporcjonalne, jeżeli są w wystarczającym stopniu rekompensowane ze środków publicznych. Instytucja ta znalazła się w prawie polskim w związku z art. 2 Konwencji z dnia 13 grudnia 2006 r. o prawach osób niepełnosprawnych ${ }^{27}$ oraz art. 5 dyrektywy Rady z dnia 27 listopada 2000 r. ustanawiającej ogólne warunki ramowe równego traktowania w zakresie zatrudnienia i pracy ${ }^{28}$. Celem jej jest umożliwienie osobie niepełnosprawnej uczestnictwa i rozwoju w zatrudnieniu.

Wskazane powyżej koszty dodatkowe zatrudniania, a zatem koszty, których nie ponosi pracodawca zatrudniający osoby pełnosprawne ${ }^{29}$, mogą zostać uzupełnione o zwrot kosztów poniesionych w związku z rozpoznaniem przez służby medycyny pracy potrzeb adaptacji pomieszczeń, adaptacji lub nabycia urządzeń ułatwiających osobie niepełnosprawnej wykonywanie pracy, zakupu i autoryzacji oprogramowania i urządzeń technologii wspierających wspomagających osoby niepełnosprawne.

Refundacja kosztów uregulowana w art. 26d ustawy o rehabilitacji zawodowej dotyczy w istocie miesięcznych kosztów zatrudnienia i szkolenia pracownika pomagającego pracownikowi niepełnosprawnemu. Stanowi to dalej idącą pomoc w zakresie wykonywania przez osoby niepełnosprawne obowiązków pracowni$\mathrm{czych}^{30}$. Zakres tej refundacji jest związany z czynnościami ułatwiającymi komunikowanie się z otoczeniem, a także czynności niemożliwe lub trudne do samodzielnego wykonania przez pracownika niepełnosprawnego na stanowisku pracy.

E. Staszewska, Środki prawne..., s. 238.

Zob. szerzej M. Paluszkiewicz, Obowiązek pracodawcy zapewnienia osobie niepełnosprawnej niezbędnych racjonalnych usprawnień, [w:] T. Bińczycka-Majewska, M. Włodarczyk, Współczesne problemy prawa emerytalnego, Warszawa 2015, s. 317.

Dz.U. z 2012 r. poz. 1169.

Dz.Urz. UE L 2000.303.16.

J. Knapińska, Nowe zasady..., s. 9.

E. Staszewska, [w:] Ustawa o rehabilitacji..., s. 538. 
Wspieranie zatrudnienia osób niepełnosprawnych na otwartym rynku pracy

W tym przypadku o refundację kosztów mogą ubiegać się jedynie pracodawcy zatrudniający już osoby niepełnosprawne, a nie dopiero zamierzający ich zatrudniać.

\section{Dostęp osób niepełnosprawnych do instrumentów i usług rynku pracy}

Wśród działań wyrównawczych wskazuje się również w obowiązującej regulacji prawo korzystania przez osoby niepełnosprawne z usług lub instrumentów rynku pracy na zasadach określonych w ustawie z dnia 20 kwietnia 2004 r. o promocji zatrudnienia i instytucjach rynku pracy ${ }^{31}$. Z uprawnień przewidzianych $\mathrm{w}$ tej ustawie mogą skorzystać osoby niepełnosprawne, zarejestrowane w powiatowym urzędzie pracy jako bezrobotne, oraz osoby niepełnosprawne, zarejestrowane w powiatowym urzędzie pracy jako poszukujące pracy, niepozostające w zatrudnieniu (art. 11 ustawy o rehabilitacji zawodowej). Na marginesie warto zauważyć, że wskazany powyżej generalny system odesłania zastosowany w ustawie o rehabilitacji do ustawy o promocji zatrudnienia nie ułatwia ustalenia, do jakich usług i instrumentów przysługuje dostęp osobom niepełnosprawnym.

W myśl art. 35 ust. 1 ustawy o promocji zatrudnienia do usług rynku pracy należą: pośrednictwo pracy, poradnictwo zawodowe oraz organizacja szkoleń. Należy przy tym zauważyć, że kwestia szkoleń uregulowana została również w rozdziale 8 ustawy o rehabilitacji zawodowej ${ }^{32}$. W literaturze słusznie postuluje się de lege ferenda, aby problematyka szkoleń osób niepełnosprawnych uregulowana była $\mathrm{w}$ jednym miejscu ${ }^{33}$.

Ponadto osoby bezrobotne niepełnosprawne zostały zaliczone do osób w szczególnej sytuacji prawnej na rynku pracy (art. 49 ustawy z 20 kwietnia 2004 r. o promocji zatrudnienia i instytucjach rynku pracy). Oznacza to, że do tych osób moga być stosowane nie tylko zwykłe instrumenty aktywizacji, ale także szczególne. Osobom tym przysługuje pierwszeństwo w skierowaniu do udziału w programach specjalnych. Związane jest to ze szczególnym zagrożeniem pozostawania tych osób poza zatrudnieniem ${ }^{34}$. Do szczególnych instrumentów aktywizacji należą przykładowo: finansowanie kosztów przejazdu do pracodawcy zgłaszającego ofertę pracy

31 Zob. tekst jedn. Dz.U. z 2020 r. poz. 1409.

32 Szerzej na ten temat E. Bielak-Jomaa, [w:] Ustawa o rehabilitacji zawodowej i społecznej oraz zatrudnianiu osób niepełnosprawnych. Komentarz, red. M. Włodarczyk, Warszawa 2015, s. 742 i n.

33 Tak E. Staszewska, [w:] Ustawa o rehabilitacji..., s. 323. Zob. też E. Bielak-Jomaa, Szkolenia osób bezrobotnych i poszukujących pracy jako forma aktywizacji zawodowej - kilka uwag krytycznych, [w:] Prawo a niepełnosprawność. Wybrane aspekty, red. M. Bosak, Warszawa 2015, s. 115 i n.

34 M. Szabłowska, Wyrównywanie szans osób niepełnosprawnych w zakresie dostępu do zatrudnienia na otwartym rynku pracy, „Polityka Społeczna” 2013, nr 10, s. 21. 
lub do miejsca pracy, prace interwencyjne, staż dla bezrobotnych i przygotowanie zawodowe dorosłych, system bonów.

Podkreślenia wymaga, że zastosowanie specjalnych instrumentów aktywizacji osób niepełnosprawnych do niedawna związane było z ustalaniem tzw. profilu pomocy. Artykuł 33 ust. 2 b ustawy o promocji zatrudnienia przewidywał, że powiatowy urząd pracy, udzielając bezrobotnemu pomocy, niezwłocznie po rejestracji, ustala dla bezrobotnego profil pomocy, oznaczający właściwy ze względu na potrzeby bezrobotnego zakres form pomocy określonych w ustawie. W myśl art. 34a ust. $3 c$ cytowanej ustawy minister właściwy do spraw pracy określał w drodze rozporządzenia sposób ustalenia profilu pomocy oraz postępowanie $w$ ramach profili pomocy, mając na uwadze zwiększenie szans bezrobotnego na rynku pracy ${ }^{35}$. W literaturze profilowanie oceniano raczej krytycznie. Wskazywano m.in. na wątpliwości dotyczące momentu, w którym ustalany jest profil pomocy dla bezrobotnego („niezwłocznie po rejestracji”), zgodności tych przepisów z zasadą równości wobec prawa oraz z regułami dotyczącymi ochrony danych osobowych ${ }^{36}$. W związku z powyższym potrzeba zmiany istniejących przepisów była podnoszona również przez przedstawicieli resortu pracy ${ }^{37}$.

Powyżej cytowane przepisy zostały uchylone z dniem 14 czerwca $2019 \mathrm{r}^{38}$ Oceny tych przepisów dokonał Trybunał Konstytucyjny w wyroku z dnia 6 czerwca 2018 r. ${ }^{39}$, w którym orzekł, że art. 33 ust. 2b ustawy o promocji zatrudnienia w zakresie, w jakim nie przewiduje odrębnego środka zaskarżenia czynności ustalenia dla bezrobotnego profilu pomocy, jest zgodny z Konstytucją. Z kolei art. 34a ust. $3 c$ ustawy o promocji zatrudnienia zdaniem Trybunału Konstytucyjnego jest niezgodny z Konstytucją z dwóch powodów. Po pierwsze, przepis ten narusza wymóg ustawowej regulacji zasad i trybu zbierania informacji o jednostkach. Pozwala na uregulowanie $\mathrm{w}$ rozporządzeniu zakresu danych zbieranych $\mathrm{w}$ trakcie profilowania, sposobu ich pozyskiwania, przetwarzania, poprawiania i udostępniania. Po drugie, przepis ten nie zawiera dostatecznych wytycznych do wydania aktu wykonawczego w sprawie profilowania. W związku z tym, że „podczas rozpatrywania powyższej sprawy ujawniły się liczne wady procedury profilowania, które z powodów formalnych nie mogły być przedmiotem wyroku", Trybunał Konstytucyjny

35 Nieobowiązujące już rozporządzenie Ministra Pracy i Polityki Społecznej z dnia 14 maja 2014 r. w sprawie profilowania pomocy dla bezrobotnego (Dz.U. z 2014 r. poz. 631).

Szerzej zob. Z. Góral, [w:] Ustawa o promocji zatrudnienia i instytucjach rynku pracy. Komentarz, red. Z. Góral, Warszawa 2016, s. 317-318; A. Drabek, Profilowanie pomocy dla bezrobotnych jako nowy sposób na walkę z bezrobociem?, „Gdańsko-Łódzkie Roczniki Prawa Pracy i Prawa Socjalnego” 2014, nr 4, s. 21 i n. „Gazeta Prawna”, 18.05.2016; M. Topolewska, Rewolucja w urzędach pracy. Koniec obowiązkowego profilowania bezrobotnych, „Gazeta Prawna”, 25.01.2017.

38 Ustawa z dnia 26 kwietnia 2019 r. o zmianie ustawy o promocji zatrudnienia i instytucjach rynku pracy (Dz.U. z 2019 r. poz. 986).

$39 \mathrm{~K} \mathrm{53/16} \mathrm{K} \mathrm{53/16,} \mathrm{OTK-A} \mathrm{2018,} \mathrm{nr} 38$. 
Wspieranie zatrudnienia osób niepełnosprawnych na otwartym rynku pracy

zdecydował się zwrócić na nie uwagę ustawodawcy, wydając postanowienie $\mathrm{z}$ dnia 6 czerwca 2018 r. ${ }^{40}$ Ponadto, jak stwierdził Trybunał, za potrzebą takiej sygnalizacji istniejących problemów przemawia „społeczne znaczenie problemu bezrobocia i fakt, że zjawisko to dotyczy osób wymagających najczęściej szczególnej pomocy państwa”.

Trybunał poddał pod wątpliwość, czy omawiane przepisy o profilowaniu osób bezrobotnych dostatecznie chronią dane osobowe bezrobotnych poddanych procedurze profilowania. W ocenie trybunału ustawodawca powinien zwrócić uwagę na następujące problemy. Po pierwsze, przepisy dotyczące profilowania nie przewidują wyraźnej zgody bezrobotnego na ujawnienie przez niego danych o swojej osobie. Równocześnie niewyrażenie zgody na profilowanie jest zagrożone bardzo surową sankcją w postaci obligatoryjnego skreślenia z rejestru bezrobotnych. Po drugie, przepisy te nie zawierają regulacji dotyczących czasu przechowywania danych pochodzących $z$ profilowania oraz zasad i procedur realizacji przez bezrobotnego praw wynikających z przekazania przez niego danych osobowych urzędowi pracy. Po trzecie, przepisy dotyczące profilowania nie przesądzają, czy ustalenie profilu ma się odbywać w sposób całkowicie zautomatyzowany, czy też dopuszczalna jest ręczna korekta ustaleń systemu komputerowego przez pracownika urzędu pracy.

Przedstawione wady regulacji dotyczącej profilowania osoby bezrobotnej słusznie spowodowały, iż została ona usunięta. Pozostał tzw. indywidualny plan działania (art. 34a ustawy o promocji zatrudnienia), chociaż odpowiednio znowelizowany w 2019 r. $^{41}$ Istotne w mojej ocenie jest to, że obecnie program ten nie musi być już poprzedzony profilowaniem bezrobotnego. Przede wszystkim w myśl nowej regulacji stanowi on pomoc udzielaną przez powiatowy urząd pracy bezrobotnemu lub poszukującemu pracy w sposób dostosowany do indywidualnych potrzeb i możliwości bezrobotnego lub poszukującego pracy - z uwzględnieniem jego wykształcenia, doświadczenia zawodowego oraz możliwości podjęcia pracy lub działalności gospodarczej. W wyniku nowelizacji odstąpiono od warunku, aby w indywidualnym planie działania mogły być stosowane jedynie te formy pomocy, które zostały przewidziane dla danego profilu. Zaletą tego programu jest również to, że nie jest przygotowywany automatycznie, ale przez doradcę klienta - przy udziale bezrobotnego lub poszukującego pracy. Pozytywnie należy również ocenić obecne brzmienie przepisu, które wskazuje na obligatoryjność modyfikacji indywidualnego planu działania stosownie do zmieniającej się sytuacji bezrobotnego lub poszukującego pracy („indywidualny plan działania podlega modyfikacji”). Do noweli z 2019 r. modyfikacja indywidualnego planu była raczej fakultatywna („indywidu-

40 S 3/18, OTK-A 2018, $\mathrm{nr} 36$.

41 Ustawa z dnia 26 kwietnia 2019 r. o zmianie ustawy o promocji zatrudnienia i instytucjach rynku pracy (Dz.U. z 2019 r. poz. 986). 
alny plan działania może być modyfikowany"). W celu monitorowania sytuacji i dokonania ewentualnych modyfikacji przewidziano, że urząd pracy powinien kontaktować się z tą osobą co najmniej raz na 60 dni.

\section{Samozatrudnienie osób niepełnosprawnych}

Aktywizacja osób niepełnosprawnych na otwartym rynku pracy może odbywać się poprzez wspieranie samozatrudnienia tych osób ze środków publicznych. Rozwiązanie to dotyczy osób niepełnosprawnych zarejestrowanych w powiatowym urzędzie pracy jako bezrobotni albo poszukujący pracy niepozostający w zatrudnieniu. Pomoc finansowa może polegać na otrzymaniu $\mathrm{z}$ funduszu PFRON jednorazowych środków na podjęcie działalności gospodarczej, rolniczej albo działalności w formie spółdzielni socjalnej (art. 12a ustawy o rehabilitacji zawodowej) ${ }^{42}$. Wysokość wypłacanych środków powinna zostać określona $\mathrm{w}$ drodze negocjacji $\mathrm{w}$ umowie zawartej ze starostą. W wyniku nowelizacji z $2018 \mathrm{r}^{43}$ wysokość ta nie może przekraczać 6-krotności przeciętnego wynagrodzenia $\mathrm{w}$ przypadku zobowiązania się osoby niepełnosprawnej do prowadzenia wskazanych działalności nieprzerwanie przez okres co najmniej 12 miesięcy albo od 6-krotności do 15-krotności przeciętnego wynagrodzenia, gdy okres ten ulega wydłużeniu do 24 miesięcy.

W świetle powyższej regulacji powstało kontrowersyjne zagadnienie, jaka jest forma rozpatrzenia wniosku o udzielenie pomocy. Zdaniem części sądów administracyjnych rozstrzygnięcie w sprawie wniosku nie jest ani decyzją administracyjną, ani innym aktem czy czynnością podlegającą kognicji sądów administracyjnych ${ }^{44}$. $\mathrm{Z}$ kolei w innych sprawach sąd stwierdzał, że jest to decyzja administracyjna ${ }^{45}$. Ostatecznie kwestię tę rozstrzygnął Naczelny Sąd Administracyjny w Warszawie w uchwale z dnia 24 maja 2012 r., w której wskazał, że właściwą formą jest decyzja administracyjna ${ }^{46}$.

Pomoc finansową ze środków Funduszu może także otrzymać osoba niepełnosprawna, która już prowadzi działalność gospodarczą albo własne lub dzierżawione gospodarstwo rolne (art. 13 ustawy o rehabilitacji zawodowej). Polega ona na dofinansowaniu do wysokości 50\% oprocentowania kredytu bankowego zaciągniętego na kontynuowanie tej działalności, a także na refundacji składek na ubezpieczenie

Rozporządzenie Ministra Rodziny, Pracy i Polityki Społecznej z dnia 12 grudnia 2018 r. w sprawie przyznania osobie niepełnosprawnej środków na podjęcie działalności gospodarczej, rolniczej albo działalności w formie spółdzielni socjalnej (Dz.U. z 2018 r. poz. 2342).

Ustawa z dnia 15 grudnia 2017 r. o zmianie ustawy o spółdzielniach socjalnych oraz niektórych innych ustaw (Dz.U. z 2017 r. poz. 2494).

Zob. m.in. postanowienie WSA w Łodzi z dnia 15 września 2010 r., II SA/Łd 797/10, LEX nr 773058.

Zob. np. postanowienie WSA w Gdańsku z dnia 18 września 2014 r., I SA/Gd 1093/14, LEX nr 1505080.

Uchwała NSA z dnia 24 maja 2017 r., IIGPF 1/12, ONSA 2012, nr 4, poz. 62, s. 74. 
Wspieranie zatrudnienia osób niepełnosprawnych na otwartym rynku pracy

społeczne. W przypadku tej pomocy osoba niepełnosprawna nie musi posiadać statusu osoby bezrobotnej albo poszukującej pracy.

\section{Uwagi końcowe}

Przedstawione rozważania pokazują, że istnieje wiele różnych rozwiązań wspierających zatrudnienie osób niepełnosprawnych na otwartym rynku pracy. Pomimo tego poziom aktywności tych osób jest nadal niezadowalający. Jak wynika z danych statystycznych (BAEL GUS), w 2018 r. współczynnik aktywności zawodowej osób z niepełnosprawnościami w wieku produkcyjnym wyniósł 28,3\%, wskaźnik zatrudnienia - 26,2\%, a stopa bezrobocia $-7,2 \%{ }^{47}$.

Przyczyny takiego stanu rzeczy są, w mojej ocenie, zróżnicowane. Przeprowadzone rozważania pokazują, że przyczyn tych należy poszukiwać również w mankamentach istniejących dotychczas regulacji prawnych. Niektóre z nich utrudniają dostęp do przewidzianych środków wspierania osób niepełnosprawnych. Dotyczy to przykładowo dostępu do korzystania z usług i instrumentów rynku pracy, który zasadniczo przysługuje bezrobotnym i poszukującym pracy. Wbrew pozorom uzyskanie przez osobę niepełnosprawną statusu osoby bezrobotnej może być utrudnione, biorąc pod uwagę, że niezbędna jest zdolność do podjęcia zatrudnienia oraz niepobieranie takich świadczeń jak renta z tytułu niezdolności do pracy, renta szkoleniowa czy socjalna.

Istnieją także regulacje, które wywołują wątpliwości w kwestii dochodzenia roszczeń.

W tym kontekście niejasne są zasady kwestionowania na drodze administracyjnej i sądowej aktów i czynności, które są podejmowane przez komisje powołane do przeprowadzenia naboru na stanowisko przewidzianego w ustawie o służbie cywilnej i w ustawie o pracownikach samorządowych. W szczególności rodzi się pytanie, jaki sąd jest właściwy w sprawach spornych.

Przyczyny niskiego poziomu aktywności osób niepełnosprawnych widoczne są również w obszarach pozaprawnych. W związku z powyższym warto $\mathrm{w}$ większym stopniu stosować instrumenty pozaprawne włączające osoby niepełnosprawne do społeczeństwa. Można tutaj wskazać przełamywanie barier architektonicznych, komunikacyjnych. Bardzo ważne w przeciwdziałaniu wykluczeniu osób niepełnosprawnych z rynku pracy jest również dostrzeżenie przez samych niepełnosprawnych i ich rodziny roli edukacji w przygotowaniu tych osób do wymogów rynku pracy oraz roli nieustannego podnoszenia kwalifikacji w celu zwiększenia szans tych osób na zatrudnienie. 


\section{Akty prawne}

Konwencja z dnia 13 grudnia 2006 r. o prawach osób niepełnosprawnych (Dz.U. z 2012 r. poz. 1169).

Dyrektywa Rady z dnia 27 listopada 2000 r. ustanawiająca ogólne warunki ramowe równego traktowania w zakresie zatrudnienia i pracy (Dz.Urz. UE L 2000.303.16).

Ustawa z dnia 27 sierpnia 1997 r. o rehabilitacji zawodowej i społecznej oraz zatrudnianiu osób niepełnosprawnych (tekst jedn. Dz.U. z 2020 r. poz. 426).

Ustawa z dnia 20 kwietnia 2004 r. o promocji zatrudnienia i instytucjach rynku pracy (tekst jedn. Dz.U. z 2020 r. poz. 1409).

Ustawa z dnia 21 listopada 2008 r. o służbie cywilnej (tekst jedn. Dz.U. z 2020 r. poz. 226).

Ustawa z dnia 21 listopada 2008 r. o pracownikach samorządowych (tekst jedn. Dz.U. z 2019 r. poz. $1282 \mathrm{z}$ późn. zm.).

Ustawa z dnia 15 grudnia 2017 r. o zmianie ustawy o spółdzielniach socjalnych oraz niektórych innych ustaw (Dz.U. z 2017 r. poz. 2494).

Ustawa z dnia 26 kwietnia 2019 r. o zmianie ustawy o promocji zatrudnienia i instytucjach rynku pracy (Dz.U. z 2019 r. poz. 986).

Rozporządzenie Ministra Pracy i Polityki Socjalnej z dnia 18 września 1998 r. w sprawie rodzajów schorzeń uzasadniających obniżenie wskaźnika zatrudnienia osób niepełnosprawnych oraz sposobu jego obniżenia (Dz.U. z 1998 r. Nr 124, poz. 820).

Rozporządzenie Ministra Pracy i Polityki Społecznej z dnia 11 marca 2011 r. w sprawie zwrotu kosztów wyposażenia stanowiska pracy osoby niepełnosprawnej (Dz.U. z 2015 r. poz. 93).

Rozporządzenie Ministra Pracy i Polityki Społecznej z dnia 14 maja 2014 r. w sprawie profilowania pomocy dla bezrobotnego (Dz.U. z 2014 r. poz. 631).

Rozporządzenie Ministra Pracy i Polityki Społecznej z dnia 23 grudnia 2014 r. w sprawie zwrotu dodatkowych kosztów związanych z zatrudnianiem pracowników niepełnosprawnych (Dz.U. z 2014 r. poz. 1987).

Rozporządzenie Ministra Rodziny, Pracy i Polityki Społecznej z dnia 12 grudnia 2018 r. w sprawie przyznania osobie niepełnosprawnej środków na podjęcie działalności gospodarczej, rolniczej albo działalności w formie spółdzielni socjalnej (Dz.U. z 2018 r. poz. 2342).

\section{Orzecznictwo}

Postanowienie TK z dnia 6 czerwca 2018 r., S 3/18, OTK-A 2018, nr 36.

Wyrok TK z dnia 6 czerwca 2018 r., K 53/16 K 53/16, OTK-A 2018, nr 38.

Uchwała SN z dnia 29 czerwca 2006 r., III PZP 1/06, OSNAPiUS 2007, nr 3-4, poz. 37.

Uchwała NSA z dnia 24 maja 2017 r., IIGPF 1/12, ONSA 2012, nr 4, poz. 62.

Wyrok NSA z dnia 13 grudnia 2017 r., II GSK 2782/17, LEX nr 2435573.

Postanowienie WSA w Łodzi z dnia 15 września 2010 r., II SA/Łd 797/10, LEX nr 773058. 
Wspieranie zatrudnienia osób niepełnosprawnych na otwartym rynku pracy

Postanowienie WSA w Warszawie z dnia 13 czerwca 2011 r., VII SA/Wa 2354/10, Legalis nr 510158.

Postanowienie WSA w Warszawie z dnia 14 maja 2013 r., IV SA/Wa 595/13, Legalis nr 846376.

Postanowienie WSA w Gdańsku z dnia 18 września 2014 r., I SA/Gd 1093/14, LEX nr 1505080.

Postanowienie WSA we Wrocławiu z dnia 2 lipca 2018 r., IV SA/Wr 54/18, Legalis nr 1804735.

Wyrok WSA w Warszawie z dnia 31 maja 2006 r., III SA/Wa 353/06, Legalis nr 320881.

Wyrok WSA w Warszawie z dnia 22 listopada 2016 r., III SA/Wa 2694/15, LEX nr 2260907.

Wyrok WSA w Warszawie z dnia 18 października 2018 r., V SA/Wa 1631/18, LEX nr 2643547.

Wyrok WSA w Warszawie z dnia 15 stycznia 2019 r., V SA/Wa 1632/18, LEX nr 2643607.

\section{Literatura}

Baran K.W., [w:] Prawo urzędnicze. Komentarz, Warszawa 2014.

Bielak-Jomaa E., Szkolenia osób bezrobotnych i poszukujacych pracy jako forma aktywizacji zawodowej - kilka uwag krytycznych, [w:] Prawo a niepetnosprawność. Wybrane aspekty, red. M. Bosak, Warszawa 2015.

Bielak-Jomaa E., [w:] Ustawa o rehabilitacji zawodowej i społecznej oraz zatrudnianiu osób niepetnosprawnych. Komentarz, red. M. Włodarczyk, Warszawa 2015.

Drabek A., Profilowanie pomocy dla bezrobotnych jako nowy sposób na walkę z bezrobociem?, „Gdańsko-Łódzkie Roczniki Prawa Pracy i Prawa Socjalnego” 2014, nr 4.

Dubowik A., Rygory selekcyjne i nabór do stużby cywilnej w świetle ustawy z 2008 r., „Praca i Zabezpieczenie Społeczne" 2009, nr 8.

Garlicki L., Derlatka M., [w:] Konstytucja Rzeczypospolitej Polskiej. Komentarz, t. 2, Warszawa 2016.

Góral Z., [w:] Ustawa o promocji zatrudnienia i instytucjach rynku pracy. Komentarz, red. Z. Góral, Warszawa 2016.

Klimkiewicz L., Dofinansowanie do wynagrodzeń - tylko z efektem zachęty, „Służba Pracownicza" 2010, nr 6.

Knapińska J., Nowe zasady wspierania pracodawców osób niepełnosprawnych, „Służba Pracownicza" 2009, nr 5.

Mirowska-Łoskot U., Topolewska M., Urzędy pracy znowu do reformy. Do zmiany profilowanie bezrobotnych, „Gazeta Prawna”, 18.05.2016.

Paluszkiewicz M., Obowiązek pracodawcy zapewnienia osobie niepetnosprawnej niezbędnych racjonalnych usprawnień, [w:] T. Bińczycka-Majewska, M. Włodarczyk, Wspótczesne problemy prawa emerytalnego, Warszawa 2015.

Paluszkiewicz M., [w:] Ustawa o rehabilitacji zawodowej i społecznej oraz zatrudnianiu osób niepetnosprawnych. Komentarz, red. M. Włodarczyk, Warszawa 2015. 
Roszewska K., Zatrudnianie i aktywizacja zawodowa osób z niepetnosprawnościami, [w:] Najważniejsze wyzwania po ratyfikacji przez Polskę Konwencji ONZ o prawach osób niepetnosprawnych, „Biuletyn Rzecznika Praw Obywatelskich” 2012, nr 10.

Staszewska E., Środki prawne przeciwdziałania bezrobociu, Warszawa 2012.

Staszewska E., [w:] Ustawa o rehabilitacji zawodowej i społecznej oraz zatrudnianiu osób niepełnosprawnych. Komentarz, red. M. Włodarczyk, Warszawa 2015.

Stelina J., Prawo urzędnicze, Warszawa 2009.

Szabłowska M., Wyrównywanie szans osób niepełnosprawnych w zakresie dostępu do zatrudnienia na otwartym rynku pracy, „Polityka Społeczna” 2013, nr 10.

Szewczyk H., Stosunki pracy w służbie cywilnej, Warszawa 2010.

Szewczyk H., Glosa do postanowienia SN z dnia 13 października 2005 r., II PK 337/04, OSP 2007, z. 7-8, poz. 93.

Szewczyk H., Glosa do uchwały SN z dnia 29 czerwca 2006 r., III PZP 1/06, OSP 2007, z. 12.

Topolewska M., Rewolucja w urzędach pracy. Koniec obowiązkowego profilowania bezrobotnych, „Gazeta Prawna”, 25.01.2017.

Torbus U., Równe traktowanie osób niepełnosprawnych w zatrudnieniu, [w:] Prawo a niepełnosprawność: wybrane aspekty, red. M. Bosak, Warszawa 2015. 